\title{
Bath construction at the Spanish Mediterranean seaside: maritime heritage for the coast environment
}

\author{
A. B. González Avilés ${ }^{1}$, M. I. Pérez Millán ${ }^{1} \&$ J. M. López López ${ }^{2}$ \\ ${ }^{I}$ Department of Civil Engineering, University of Alicante, Spain \\ ${ }^{2}$ Department of Building Constructions, University of Alicante, Spain
}

\begin{abstract}
The construction of buildings holding baths along the Spanish seashore, not only supposed an enjoyment for affluent people but was a way of generating a new tourist landscape. The golden age of Spanish balneotherapy took place around the last third of the nineteenth century. Many sea bath structures were built at the Spanish Levante, but they have all now disappeared. Inside these constructions there were coffee-shops, theaters and casinos. People used to go there looking for therapeutic or medicinal healing, and also to find a place where they could forget their problems and daily routine.

This research paper is part of a project conducted at the University of Alicante, and its main target has been to find historical documentation about these Mediterranean seashore buildings (Alicante and Murcia) in order to accomplish a cataloging that allowed us to study these architecture typologies. All the historical maps and plans, drawings and photographs used in our paper, not only offer us a romantic vision, they also convey a whole process of systematized execution. The construction system can be divided into permanent and removable structures. This removable feature and the simplicity of assembly were achieved thanks to the precarious concession carried out by the authorities at the maritime area.

This paper shows the study of different architectural, structural and constructive solutions implanted in each one of these typologies characterized by the use of fixed and removable lightweight structures and the evolution of piling systems.
\end{abstract}

Keywords: maritime heritage, sea baths, Mediterranean coast, temporary architecture. 


\section{Introduction}

In the 19th century, a sea bathing establishment or resort was a wooden construction, generally two stories high, located by the seashore. On the lower floor there were boxes where you could have a bath into sea water. The Municipal Archives of Alicante, Murcia, and other coastal towns, as well as the Murcia Costal Demarcation, held documents from the 19th and 20th centuries that testify the extended use of the words sea baths or resorts to refer to the forerunners of today's thalassotherapy centers, currently the sea baths of the 21 st century.

The first document about the setting-up of a sea bathing resort on the coast of Alicante and Murcia dates back to 1834 , dealing specifically with the wooden sea baths owned by Miguel Pascual de Bonanza [1], located by the pier opposite the market, nowadays known as Casa Carbonell.

Alicante pioneered the establishment of sea baths, before cities such as Asturias, Santander and San Sebastián.

In Asturias, they did not appear until 1874 [2]; in Santander until 1868, when the sons of Mayor Juan Pombo built the first bathing house in El Sardinero, although in 1864 there was a project for the beach at El Camello. There are no documents of earlier sea bathing resorts from other cities along the Spanish coastline, even though bathing establishments were common in places like La Coruña, Vigo, Palamós, Arenys de mar, Valencia, Murcia, Almeria and Malaga.

In 1858 , while the port area was being renovated, the location of the baths was moved to El Postiguet beach, where one of the first sea bathing resorts belonging to Juan Simó was constructed. Further resorts then sprung up, taking the total to twelve, with similar characteristics, called La Alianza, Diana, Las Delicias, Neptuno, La Florida, La Estrella, El Madrileño, El Águila, Playa del Postiguet, El Almirante, Ferrándis and Guillermo, all of them originally intended to be temporary (the temporary sea baths were dismantled at the end of the swimming season, to be re-installed during the next year. They were therefore ephemeral constructions) (Figure 1). Subsequently, La Esperanza, previously known as the Baños de Juan Simó, together with La Alianza and Diana became permanent constructions, and later on another nine temporary sea bathing resorts were erected during the bathing season. The 'aerial' photograph of the beach El Postiguet taken from Alicante castle during the summer season provides evidence of this temporary situation when it is compared to the photograph taken in winter, when such establishments were removed.

Today we can still access descriptions, photographs, postcards and the occasional unpublished map. The chronicler Figueras Pacheco, talking about Alicante, offers a description of these bathing establishments:

The right side of the boulevard, walking west to east, is limited by a broad sidewalk that separates it from the beach and acts as a seawall. All along this line, as narrow reinforced bridges erected with iron or wooden columns, and safeguarding the seaweed and the sand from the beach, we find the entrance to the bathing establishments driving the sea into the building throughout insignificant wave movements. Our bathing establishments offer a uniquely 
ventilated construction, with the sea as subsoil, where long and elegant salons stretch out. They are made up of two rows of comfortable huts, surrounded by galleries on the outside, in the manner of balconies over the waves. A short staircase of eight or ten steps leads from inside each box down to the water, allowing bathers to go down to the sea with the minimum disturbance. The comfort and elegance of these bathing establishments depend on their category; there are some baths that are truly worth visiting, for the beauty of their construction and the care with which the proprietors seek to make the bathers' stay more pleasant [3].

This description from Figueras Pacheco transport us back to the age of these sea bathing resorts, when bathing was not only a hygienic ritual with medicinal value, but one activity that would gradually become a decorous practice, more closely linked to tourist activity than medicinal purposes.

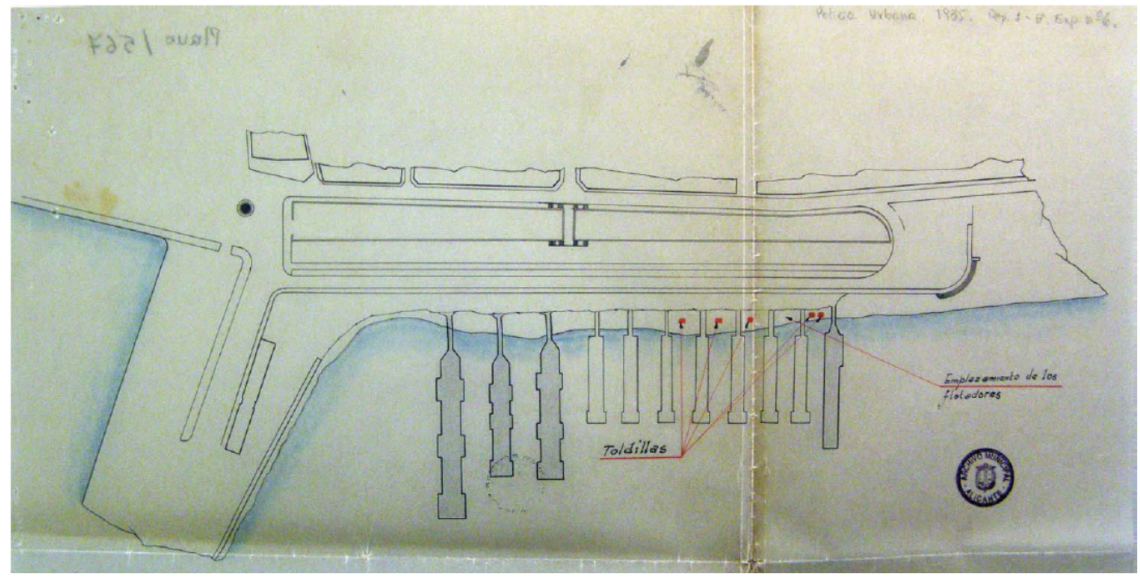

Figure 1: General map of El Postiguet circa 1935. It shows in grey the 4 fixed baths and the other 7 temporal baths. (Alicante Municipal Archives.)

\section{Typologies of seaside resorts in Alicante, El Postiguet Beach}

At the first half of the 20th century, the beach called El Postiguet held 12 seaside resorts. These resorts built in Alicante for public use, can be classified into two main architecture typologies linked with a static or dynamic condition: seaside resorts with a perpendicular structure to the coast (temporary structures) and resorts with a parallel structure to the coast (fixed structures).

- Seaside structure parallel to the coast

We can see an example in La Alianza and Diana seaside resorts. Figure 2 represents the architectural evolution where the axis orientation is perpendicular to the coast line, but its architectural structure is parallel to the coast, with an approximate length of about 120 meters, reached before the enlargement made by 1912. Around the central axis the individual booths and hot baths were 
arranged and they were supplied with sea and fresh water. At the end of the axis the restaurant with terrace were located, something that later on was very imitated by its competitors (figure 2 ).

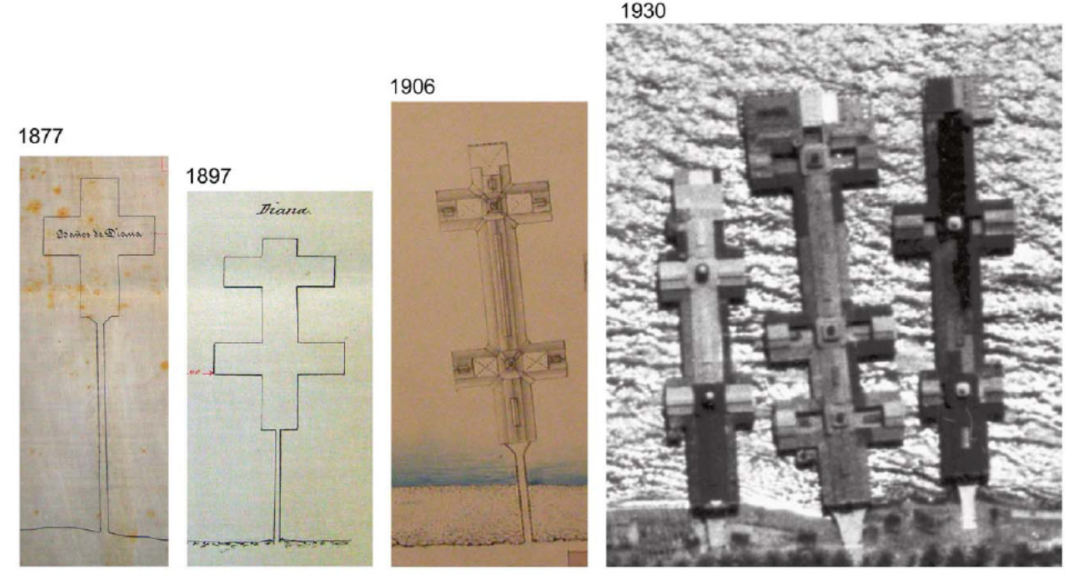

Figure 2: Alicante sea baths. Architectural evolution in Diana's sea bath.

No historical map from Diana's sea bath is preserved except the 1877 map from La Alianza sea bath which has similar typology to the Diana one. In this map that collects elevation and plan, you can see the access gateway and the double $\mathrm{T}$ ground where the changing rooms where placed in order to individually access to the sea, thanks to a small staircase (Figure 3).

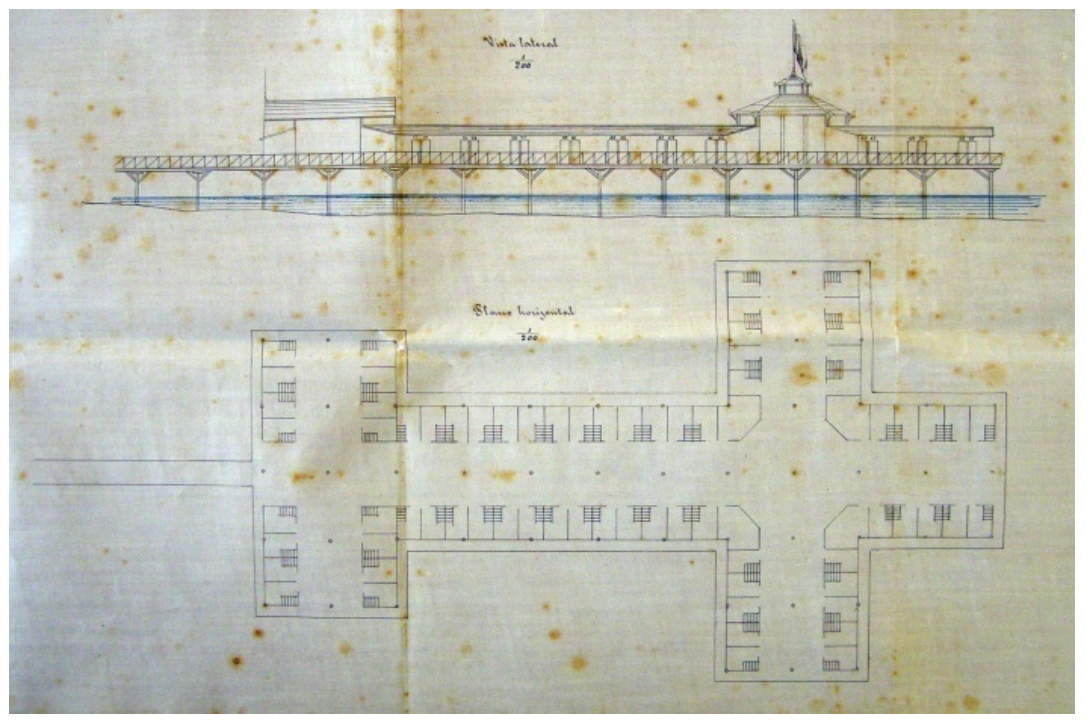

Figure 3: Plan of the Alianza Sea Bathing Resort in El Postiguet. Alicante 1877. (Alicante Provincial Archives. OP-G 180.) 


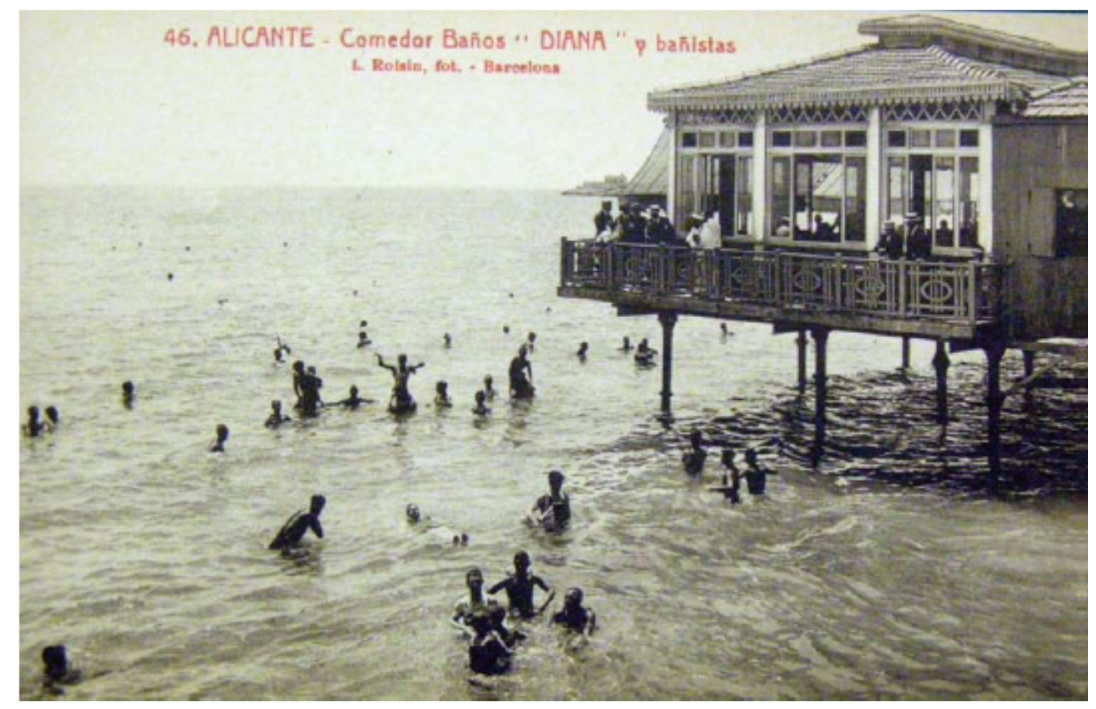

Figure 4: Diana's resort: North side view. (Gabriel Miró Library, Alicante.)

- Seaside structure perpendicular to the coast

The second architectural typology is developed perpendicular to the coast. One clear example of this typology is found at La Confianza and Estrella resorts (Figure. 5).

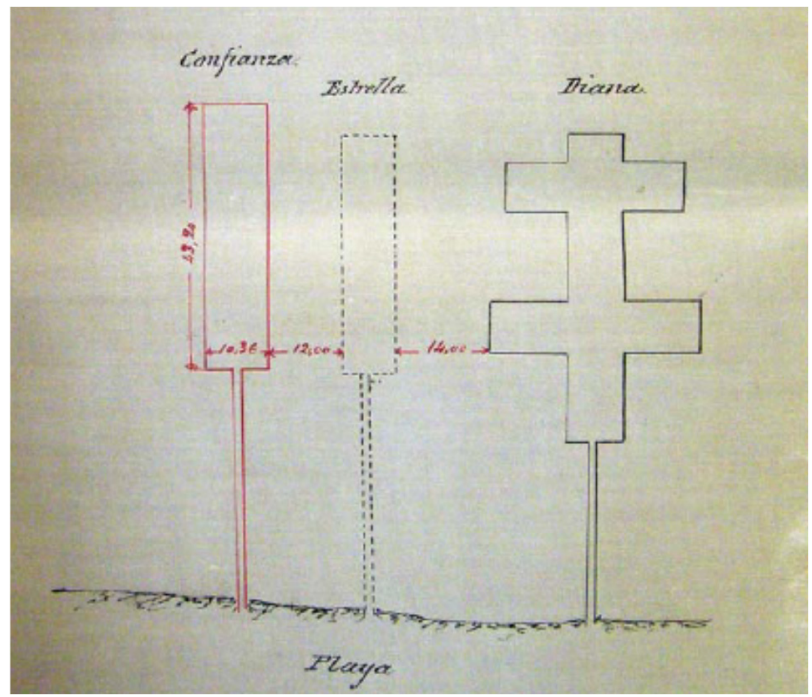

Figure 5: Site plan from La Confianza seaside resort 1877. (Alicante Provincial Archives.) 
Figure 6 shows a map of a seaside resort which includes the plan, the elevation and section of that seaside architecture perpendicular to the coastline.

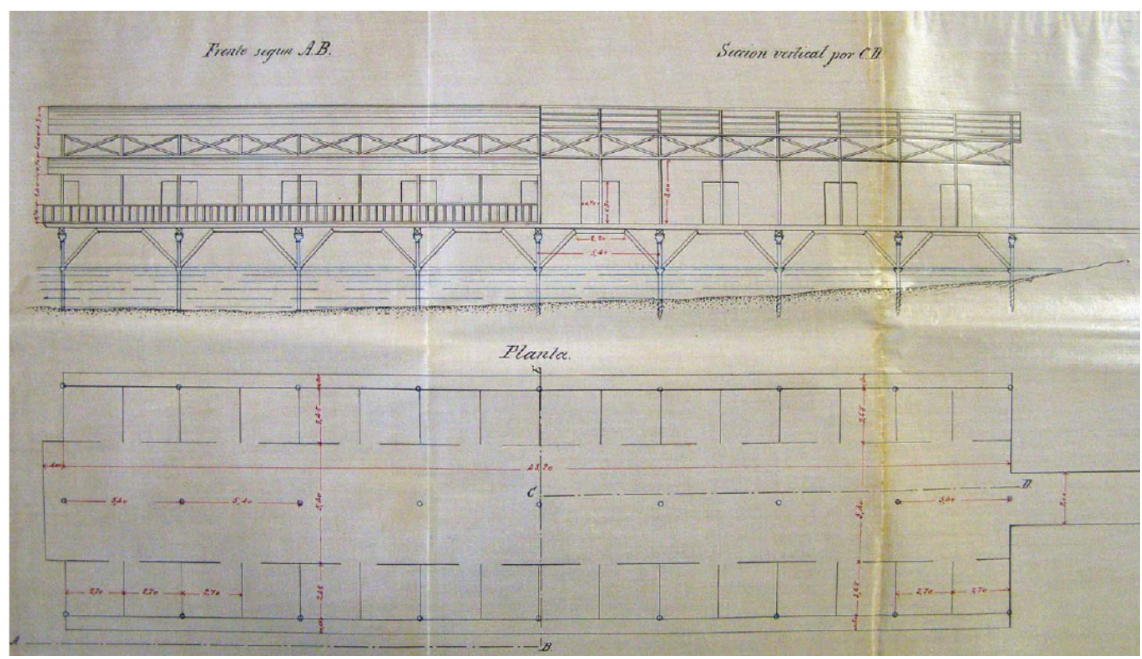

Figure 6: Drawing with dimensions of plan, elevation and longitudinal section of the La Confianza project 1897. (Alicante Provincial Archives. OP-G 180.)

\section{Constructive/structural system}

\subsection{Foundation on pilings}

Most seaside resorts repeat several construction elements in a systematic way. The pilings are a fundamental part of the facility structure, helping to raise both the gateway as the main platform above the sea level, on which the building stood.

Unlike contemporary Murcian resorts on the coast of El Mar Menor, the system of pilings of Alicante resorts consisted of a series of molten iron columns sunk into the sand and built on a foundation of hydraulic masonry, while the resorts at El Mar Menor were originally made of wood columns with a hardened tip to facilitate penetration. Subsequently these columns were covered with concrete pipes, which at the same time worked as the formwork. This way the space left between the wood pile and the concrete pipe, was perfectly filled protecting the wood against crustaceans and wave action, their main enemies [4]. The difference piling systems responded mainly to the type of sea in which they were emplaced. Those from El Mar Menor hardly suffered variation in height because of the still water coming from an almost closed sea, with small waves. In that case they used a system of wood piling which gradually was evolving until they were protected with concrete pipes. By contrast, the Mediterranean affected in a different way to the seaside structures in Alicante. In those coasts 
there was an open sea with different tides levels (although not very pronounced) and especially with heavy waves seasons. Thus in Alicante piling seaside structures were built from the beginning with molten iron sections on hydraulic masonry foundation.

For Alicante's resorts the usual span between piles was 5 and 6 meters.

The door to the walkway had the common feature of providing extensive protection. It protruded from the width of the corridor, establishing itself more as a formal emphasis as an effective functionality, and conformed a 'front' hiding behind what happened. The walkway always appears with a handrail on both sides showing different degrees of complexity, presenting sometimes a kind of pergola covering till the halfway, before reaching the platform where the booths were settled. All these elements were combined obeying to very simple schemes, with tendency to symmetry. Their finishes used to materialize with wood painted in highly decorated and bright colors, offering the typical picture of these facilities (Figure 7).

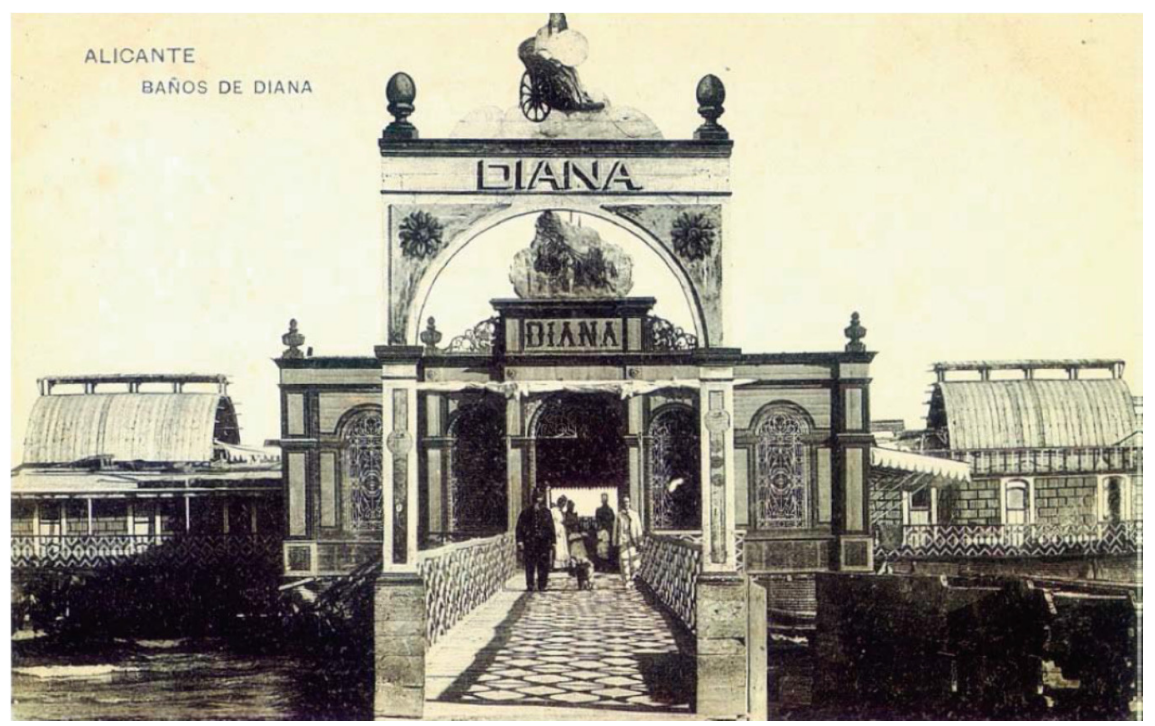

Figure 7: Entrance to the Diana resort: early 20th century.

\subsection{Horizontal platform, columns and beams}

The main structure of resorts rested on the horizontal platform which at the same time was rested on a pilings system. On the horizontal platform new wooden columns were placed between 2.5 and 3 meters distance between axes, which bore the truss system covers.

The side naves were built with wood planks working as suspenders between the central pillars in the plane of the portico. 


\subsection{Cover}

The covers, mostly inclined to one or two sides, were built with wood truss structure to achieve great lights.

In the cross section of figure 8 , it can be seen that the structural system of the cover constituting the truss was formed by inclined beams, a high strap and a suspender to give rigidity to the whole structure.

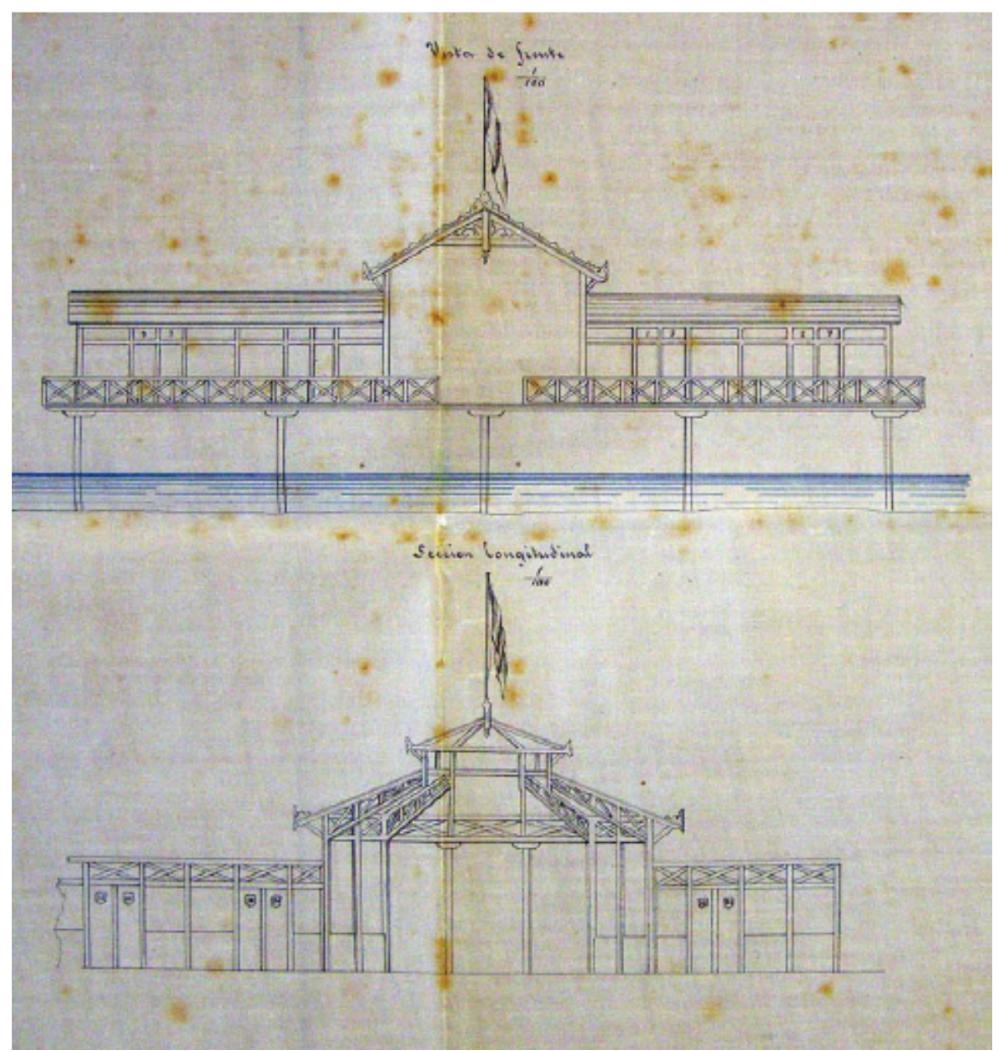

Figure 8: Elevation and cross section from the seaside resort La Alianza 1877. (Alicante Provincial Archives.)

The cover finishing was generally constituted by metal plates on metallic beams. Sometimes it could be even covered with clay or wood tiles. 


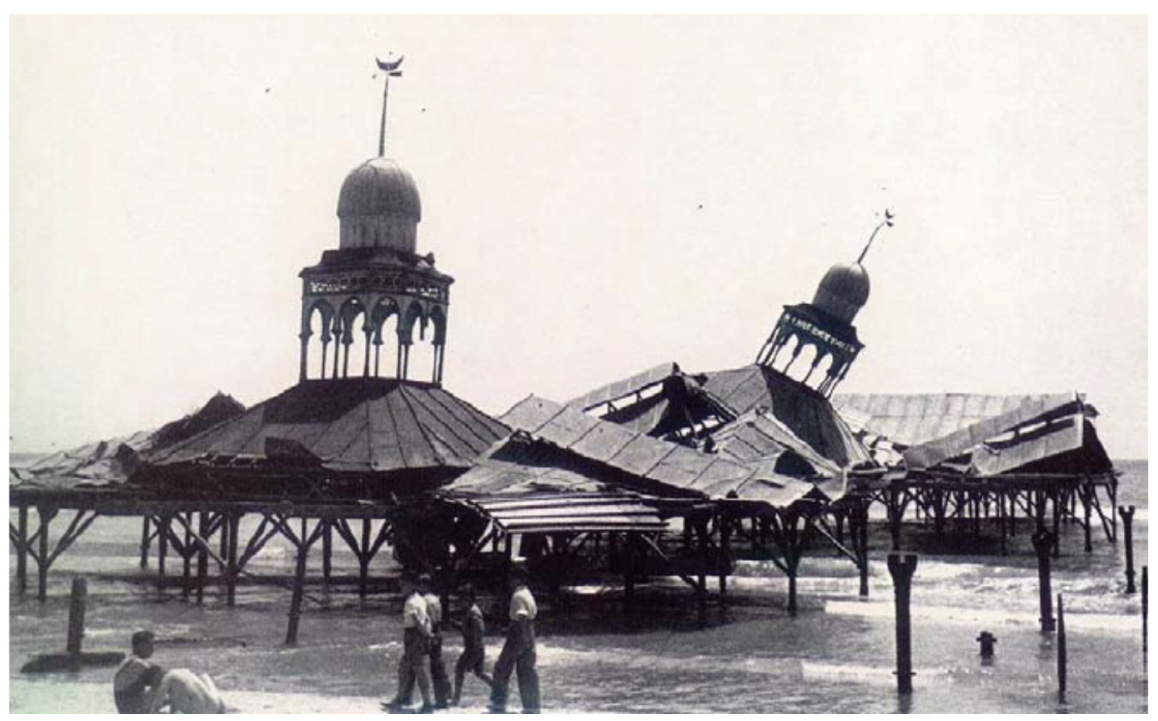

Figure 9: $\quad$ Seaside resort Alhambra after the bombing in 1938.

\section{Conclusions}

Seaside resorts were developed in response to the physical environment. The access to the sea was enclosed by a zone of mud and algae, a silt barrier that swimmers should jump to practice swimming. Thus, the first part of the resort type consisted of a very long horizontal platform that allowed to get away from the boundary formed between the sand and water.

They were constructions dedicated to the social practice of bathing, even recreational and cultural practices, because they held inside different uses such as restaurants, coffee-shops and even theaters.

The entrance, in the manner of a bridge set on pillars, which protected the first part from seaweed and sand, between the beach and the bathing establishment itself. This bridge went a fair way out into the sea because of the scarce importance of the movement of the water.

The platform, which was usually rectangular, with a central lounge area that received light from the front and through skylights. The outside was surrounded by galleries and corridors, in the manner of balconies.

Inside the bathing establishment there were large lounges and rows of bathing boxes, each containing between eight and ten steps leading down into the sea water.

They were built on wooden pilings or iron columns. The wooden pilings or stanchions were a fundamental part of the structure of the installation, raising the walkway and the main platform above sea level. 
The main element was the bathing box, with a staircase that allowed bathers to lower themselves down into the sea, protecting them from being seen by others, since the space between the platform and the water was closed in with rush matting.

In general, there was no clear distinction between interior and exterior spaces (with the exception of the bathing boxes), since these constructions built over water linked their spaces through fretwork rails, open shelters and stairways, elements that did not provide a completely effective barrier.

This was all part of the purpose of showcasing; this projected architecture was not to be lived in; rather they were areas of transition, in the fullest sense of the word; they were the link between firm land and the sea, between the air and light that invaded them, and the water that bathed them.

\section{References}

[1] Ramos Pérez, V. Historia de la provincia de Alicante y su capital, ed. Diputación Provincial, Alicante, 1971.

[2] Roza Candás, M. Los balnearios maritimos en Asturias (1848-1935), ed. Fundación Alvargonzález, Gijón, 1995, p. 81.

[3] Figueras Pacheco, F. Provincia de Alicante, in Geografía General del Reino de Valencia, IV. 1920-1927, ed. F. Carreras, Establecimiento editorial de Alberto Martín, Barcelona, 1918.

[4] Galindo Mateo, R. Balnearios del Mar Menor. Análisis histórico constructivo. Trabajo fin de Carrera de Arquitectura Técnica. Universidad de Alicante. 2002. 